\title{
AN EXPLORATORY STUDY OF USING PROFESSOR-DEVELOPED VIDEO TO TEACH WEB-BASED QUANTITATIVE METHODS COURSES
}

\author{
Andrew A. Tiger, Southeastern Oklahoma State University, atiger@se.edu \\ Kitty Campbell, Southeastern Oklahoma State University, kcampbell@se.edu \\ Jennifer M. Fitzgerald, Southeastern Oklahoma State University, jmfitzgerald@se.edu
}

\begin{abstract}
In this paper, we present an exploratory study of student satisfaction and performance in online quantitative methods courses in which professordeveloped video are a primary teaching vehicle. While video has been used extensively as a teaching tool, the literature review found little evidence of the use of professor-developed video in online quantitative methods courses. We propose that professor-developed video used in online courses offers some significant benefits such as enhanced learning, increased course satisfaction, increased faculty productivity, and intellectual property right protection. The benefits are enhanced for courses that teach spreadsheet-based analytical techniques or similar uses of software. Results from course evaluations and student surveys support our proposition of enhanced learning and increased course satisfaction.
\end{abstract}

Keywords: video instruction, Adobe Captivate, online instruction, spreadsheet-based management science instruction

\section{INTRODUCTION}

In 2003, The Association to Advance Collegiate Schools of Business (AACSB International) reintroduced management science as an expected learning experience. AACSB International had eliminated this requirement in 1991 because management science courses were viewed as irrelevant because they were being taught primarily as math courses. However, with the move towards spreadsheet modeling, growing interest in management science by business schools has lead AACSB International to reverse itself [10]. Essentially, the advent of technology created the renewed interest in management science, where the focus is on the decision-making process. In 2006, Heinrichs and McDonald [11] chaired a joint session of the Association of Business Information Systems (ABIS) and the Southwest Decision Science Institute (SWDSI) concerning IS enrollment and sustainability. Part of the discussion was the emphasis of technology in management science and the opportunity to partner for success. As evidence of the need for curriculum development of this integration, our literature search showed that current quantitative methods instruction relies on spreadsheets [16, 22].

With the emphasis on application rather than math notation, spreadsheets have become much more than charting and reporting tools. They are true productivity improvement and analysis tools used in virtually all business. In addition, spreadsheets have been used for advanced modeling techniques such as optimization and simulation using various add-ins such as Solver [17], What's Best! [20], @RISK [1], and Crystal Ball [8]. Spreadsheets have become the platform for practical quantitative modeling and analysis.

With the rapid growth of E-learning, a current challenge for professors who teach online quantitative methods courses is the development of spreadsheet instructional videos. Video as an instructional tool has been used extensively in academia. Research has demonstrated video's benefits in online courses. Choi and Johnson [6], as well as Kozma [14] found that video-based instruction was more memorable than traditional textbased learning. Baggett [3] found a critical attribute of video is the ability to use both auditory and visual symbol systems. The Cognition and Technology Group [7] found that video technology is suitable because it can convey the information in a more interesting way and allows the portrayal of complicated contexts.

Recent research exists for professor-developed video. Whatley and Ahman [21] explored the use of professor-developed video to enhance student learning. Their use of video consisted of preparing a ten minute video composed of a summary of key points. Their video was based on the "talking head" method where the availability of an expert may be critical [18]. Carrington and Green [5] discussed how today's educational technologies allow an 
educator to more readily develop quality teaching materials and perform just-in-time teaching.

Several researchers have developed tools that rely on video-based teaching. Papanikolaou et al. [15] have developed a hypermedia prototype that provides tasks that match the learner's preferred way of studying by adapting curriculum sequencing and navigation support presentation. James et al. [12] have developed a tool that enables lecturers to build their own teaching material using video. Their application of video revolved around shorts clips, up to 30 seconds, that are embedded in Blackboard. Koohang [13] explored creating learning objects than can be shared and reused in E-learning environments

The most well known non-academic use of video is the Video Professor series. Since its beginning in 1987, Video Professor claims over eight million people taught. Although limited to basic techniques and popular software, Video Professor claims that its "What-you-see-is-what-you-do" learning method is the "fastest, easiest way to learn!" [19]. The Video Professor company's success indicates that videobased learning potentially can be used for more advanced computer education such as computer information systems and quantitative methods.

Consequently, teaching spreadsheet modeling through the use of video similar to the Video Professor series would seem to be an excellent application for web-based courses. Additionally, software that allows professors to develop customized video easily, quickly and inexpensively also would be beneficial for web-based courses. One example of this type of software is Adobe Captivate [2] which retails for $\$ 699$. Other similar software exists such as Camptasia [4].

\section{OBJECTIVE}

In this paper, we propose that due to the heavy use of spreadsheets in quantitative methods instruction, online quantitative method courses are ideal for using professor-developed video as a primary teaching tool. Below, we present the results of an exploratory study of the use of professor-developed video for online quantitative methods courses.

Please note that the type of video developed is not merely a talking head that only records an instructor as he/she lectures. Rather, the videos are similar to the Video Professor series, where the student sees and hears how to use specialized software to solve quantitative methods problems. Through a player/skin, the student has the option to pause/rewind/forward, which allows the student to work in parallel with the video. For demonstrations, please go to this link: http://carmine.se.edu/atiger/video.htm .

Although, the video were accessible by the students through a player/skin, the student was not allowed to copy the files directly to their machine. The students could watch as often as needed, however, students could not copy or distribute. This provided the instructor several benefits. First, the instructor could post homework and exam solutions through video without concern that students would distribute content to future students. Second, the instructor could remove the video during exam periods. Finally, the instructor has some control over intellectual property.

\section{THE SURVEY}

As evidence of the benefits, an exploratory study was performed at a Southwestern regional university where professor-developed video have been used in online quantitative methods courses over the past two years. The videos were developed using Adobe Captivate 2 and were used primarily in online business statistics, junior-level operations management, and senior-level management science courses. Each video is about 15 minutes in length and the current library consists of approximately 40 separate videos. Video can be accessed either through Blackboard links or through the instructor's website (most popular). In the study, students and recent graduates from these courses were asked to complete an anonymous survey on the utility of professor-developed video use in online quantitative methods courses. The survey was developed using Free Online Survey.Com [9].

The students selected for participation were juniors, seniors, or recent graduates who have had at least one course that has used professor-developed video during the last 24 months. The number of students and recent graduates contacted for participation was 113. Of those, 60 participated. One likely reason for the high response rate was the opportunity of extracredit for existing students. The number of existing students who participated was 49; therefore, 11 recent graduates took the survey. The survey questions are provided in the appendix. Also, the survey can be accessed at this link: http://FreeOnlineSurveys.com/rendersurvey.asp?sid= y4yg41bh6zkqm6n388492

\section{RESULTS}


Figure 1 shows that many of the students have taken online courses; however, only a few of the courses have used professor-developed videos. Figure 2 shows that students watched the videos extensively with an average use of 50 minutes per week per student.
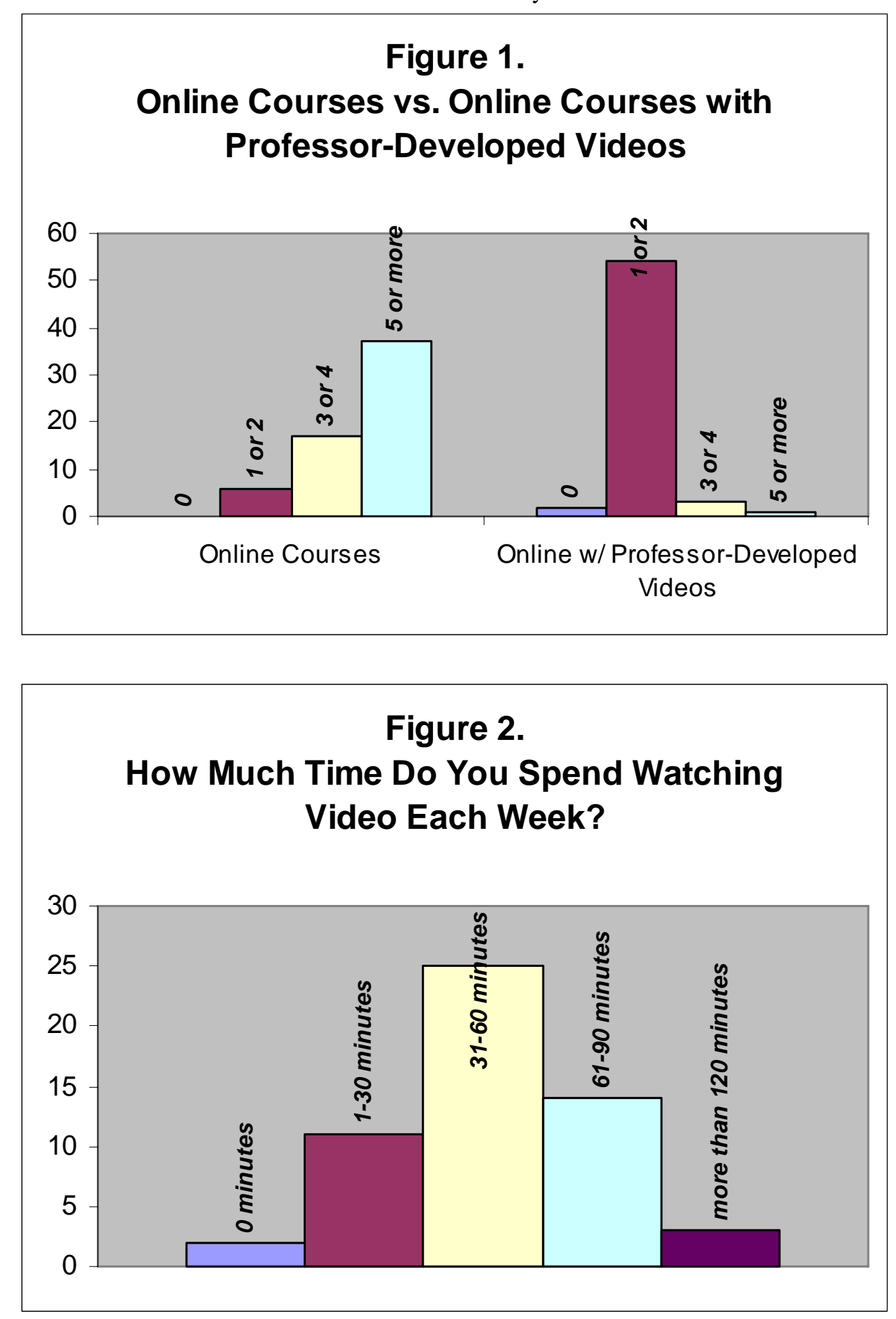

The students were asked to evaluate the usefulness of teaching tools in online courses. As Figure 3 shows, textbook, MS PowerPoint, and message boards were considered either somewhat or very useful for $80 \%$ of students. Professor-developed videos were evaluated to be to be somewhat or very useful for $95 \%$ of the 
students. Eighty percent (80\%) of the students found the professor-developed videos very useful.

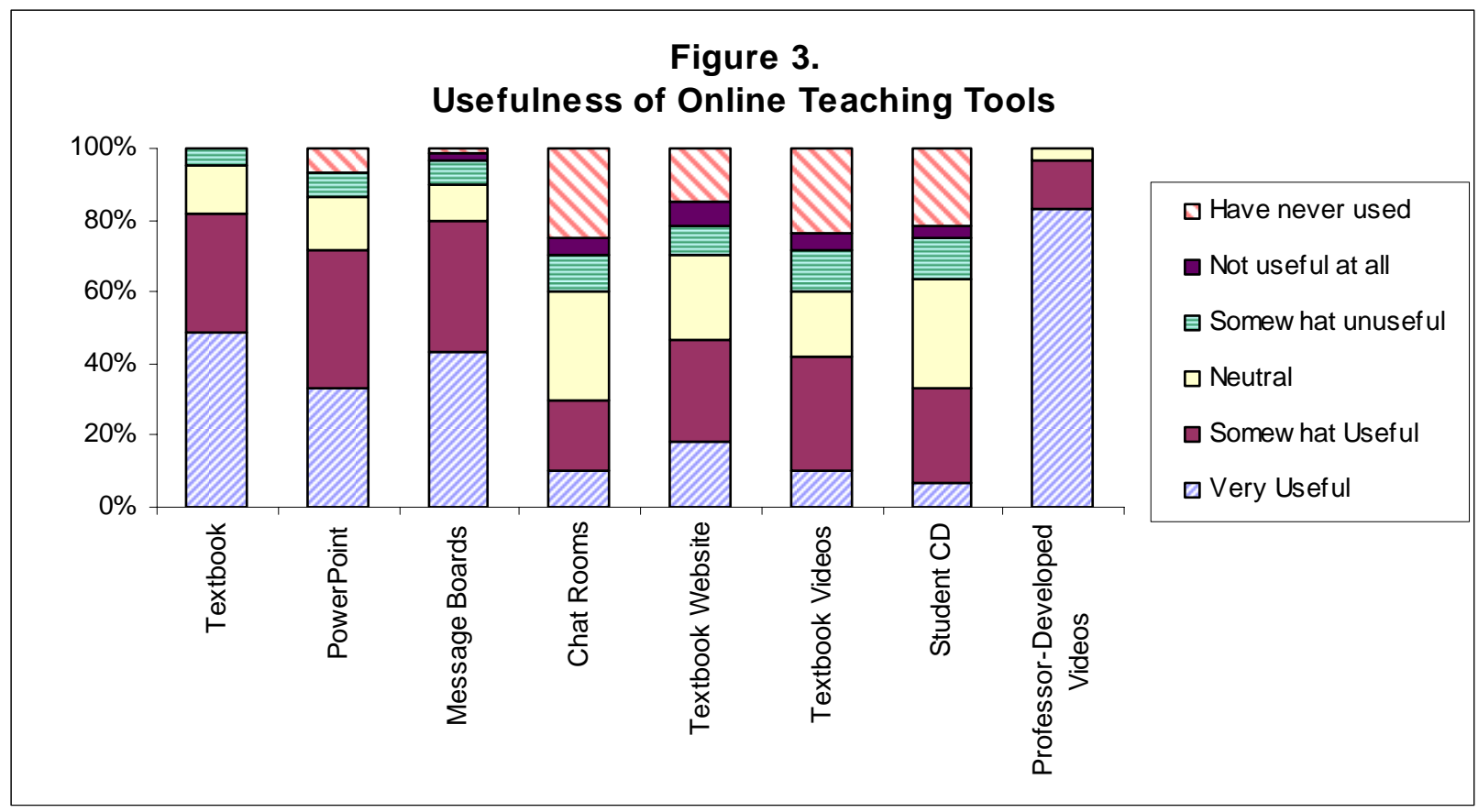

In Figure 4, students were asked to evaluate the positives (and negatives) of professor-developed videos. Since the students surveyed were known to have taken courses that used professor-developed video, it is not surprising that students rated the video favorably for spreadsheet and math skills. Also, since the videos were developed by the instructor and unique to the course, the relevancy of the material was rated very high. Because the video cannot be copied by the student, a substantial proportion of the students disagreed that the video can be copied to the PC.

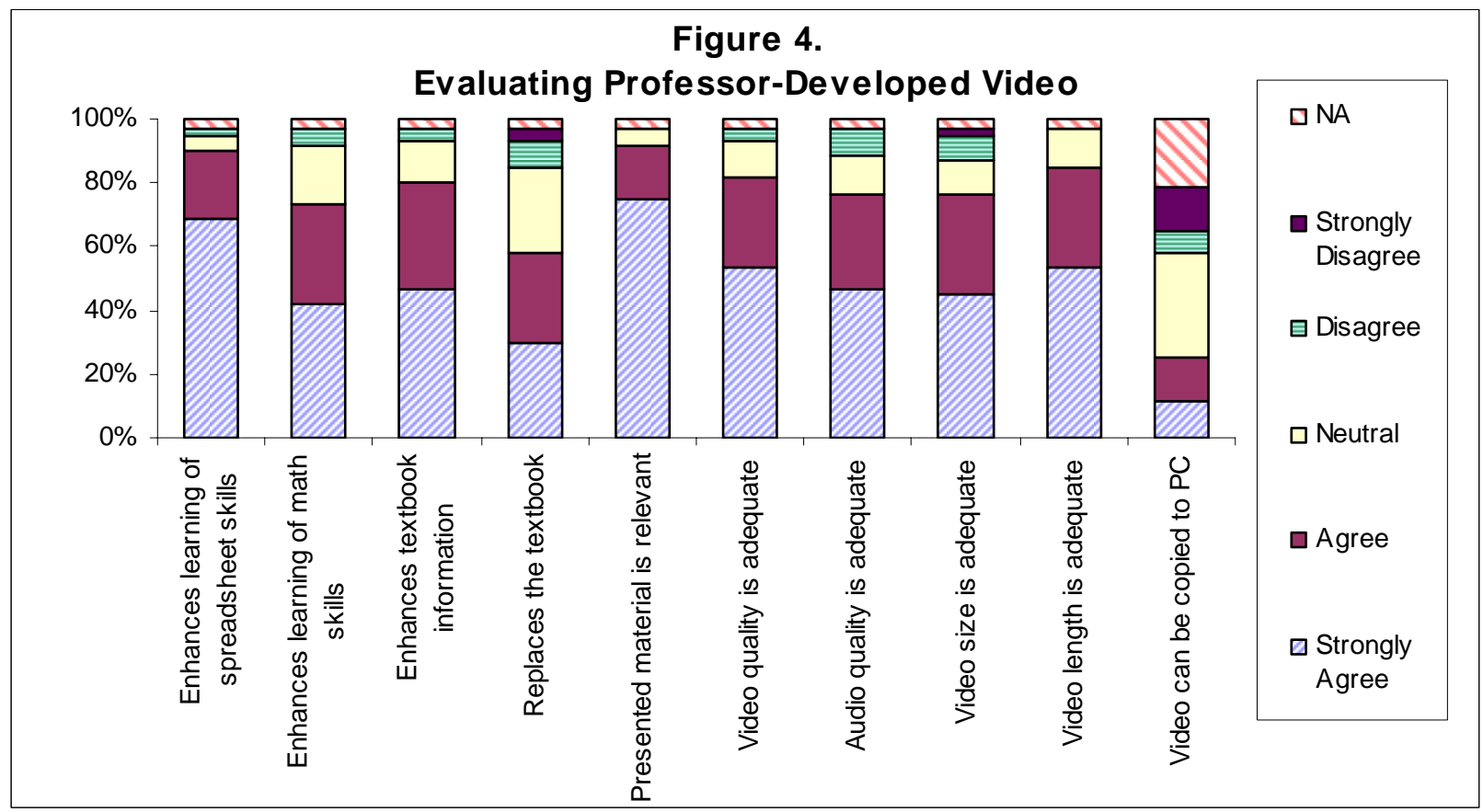


Finally, at the conclusion of the survey, students were asked for any additional comments concerning the positives and negatives. Table 1 lists a sample of the responses. One major drawback related to video production. Since the instructors were also the video producers, the instructors had to rely heavily on student feedback when producing video. One unique benefit was "It helps to know what kind of person you're talking to by seeing them and hearing their voice." This feedback shows that professordeveloped video create a rapport between the instructor and students that off-the-shelf video would be unable to achieve.

Table 1. What other benefits/drawbacks have you experienced from the use of professor-developed online course videos? Note: Responses are unedited

\begin{tabular}{|c|c|}
\hline Benefits & Drawbacks \\
\hline $\begin{array}{l}\text { You can watch the video and rework problems intil } \\
\text { you get it right!! } 1\end{array}$ & $\begin{array}{l}\text { You must be online to access them. I am not sure if } \\
\text { you can download them, but that would be useful. } \\
\text { The videos are clunky sometimes. The audio and } \\
\text { video don't always match up. The video doesn't } \\
\text { always keep up with the instructor. }\end{array}$ \\
\hline $\begin{array}{l}\text { It allows you to hear what is being taught instead of } \\
\text { just reading what is taught which is very beneficial } \\
\text { for online courses. }\end{array}$ & $\begin{array}{l}\text { that they get boring looking at the same thing th } \\
\text { whole time }\end{array}$ \\
\hline $\begin{array}{l}\text { It helps to know what kind of person you're talking } \\
\text { to by seeing them and hearing their voice. }\end{array}$ & No opportunity to ask questions. \\
\hline $\begin{array}{l}\text { They help give some of the in class feel to the online } \\
\text { classes. }\end{array}$ & $\begin{array}{l}\text { Sometimes the audio is faster then the video so it } \\
\text { gets confusing. }\end{array}$ \\
\hline $\begin{array}{l}\text { a better understanding of the methods used in } \\
\text { textbook. }\end{array}$ & $\begin{array}{l}\text { Videos do not flow with my learning style. It is hard } \\
\text { to hold my attention. }\end{array}$ \\
\hline It is almost like being in a class setting & $\begin{array}{l}\text { Drawbacks to these usually are seen only if the } \\
\text { professor rambles too much. }\end{array}$ \\
\hline $\begin{array}{l}\text { They were extremly helpful, especially in the more } \\
\text { complex classes. }\end{array}$ & Were not able to download for easier use. \\
\hline $\begin{array}{l}\text { The main benefit is that it can paused and replayed } \\
\text { any time you need to. That way you miss no } \\
\text { information offered. }\end{array}$ & $\begin{array}{l}\text { You are unable to ask questions as they arise in the } \\
\text { presentation. }\end{array}$ \\
\hline $\begin{array}{l}\text { It definitely makes learning the material much easier. } \\
\text { I strongly recommend the use of videos for upper- } \\
\text { level courses. }\end{array}$ & $\begin{array}{l}\text { The audio is not in sequence with the movement of } \\
\text { the video. }\end{array}$ \\
\hline $\begin{array}{l}\text { able to watch as many times as needed to understand } \\
\text { the materials. }\end{array}$ & $\begin{array}{l}\text { It is sometimes hard to watch the videos and "teach" } \\
\text { myself how to do it. It also takes alot of time to } \\
\text { watch the videos. }\end{array}$ \\
\hline $\begin{array}{l}\text { Completes the whole concept of bringing the } \\
\text { classroom into the home pc. }\end{array}$ & $\begin{array}{l}\text { just that you're unable to zoom in on certain } \\
\text { information to see it better. }\end{array}$ \\
\hline $\begin{array}{l}\text { I can usually refer to the problems and see a different } \\
\text { perspective or sometimes the correct formulas or } \\
\text { functions to use in Excel. }\end{array}$ & Not able to print out spreadsheets he illustrates \\
\hline $\begin{array}{l}\text { Increases the quality of online classes more than } \\
100 \% \text {. In some cases, these videos are better than } \\
\text { face-to-face class becuase you can pause and replay } \\
\text { without offending other classmates or taking up too } \\
\text { much of the professor/class time. }\end{array}$ & $\begin{array}{l}\text { Watching a video to learn is difficult for me to do. If } \\
\text { I have someone in front of me, who I can ask } \\
\text { questions to, I do great. The only drawback with } \\
\text { online courses is that it is online. I prefer the } \\
\text { professor/student interaction. }\end{array}$ \\
\hline $\begin{array}{l}\text { Professor-developed videos enhance my learning } \\
\text { experience tremendously. It replaces the classroom } \\
\text { teacher in a much better way because it can be } \\
\text { paused and replayed as many times as necessary. }\end{array}$ & It takes a long time to load. \\
\hline
\end{tabular}




\section{CONCLUSIONS}

In this paper, an exploratory study investigated the use of professor-developed video utility in online quantitative methods courses. With the use of Adobe Captivate, the authors have used professor-developed video in business statistics, operations management, and management science. Overwhelmingly, students surveyed believe that professor-developed video is very beneficial online teaching tool for quantitative methods courses.

Future research is plentiful. The most obvious is correlating the use of professor-developed video with student performance. Another research topic is investigating if professor-developed video are friendlier than other teaching methods, especially for online courses. Of interest is whether students who take most of the courses online will be interested in giving money back to their university. Friendliness would seem to be one factor in determining this interest. If so, professor-developed video may be a valuable tool for creating experiences that compel students to give back to their universities in the future.

\section{REFERENCES}

1. @Risk. (2008).

Available:

http://www.palisade.com/.

2. Adobe Captivate. (2008). Available: http://www.adobe.com/products/captivate/.

3. Baggett, P. (1984) Role of Temporal Overlap of Visual and Auditory Material in Forming Dual Medial Associations. Journal of Educational Psychology, 76(3), 408-417.

4. Camptasia. (2008). Available: http://www.techsmith.com/camtasia.asp.

5. Carrington A. and Green I. (2007). Just in Time Teaching Revisited: Using E-Assessment and Rapid E-Learning to Empower Face to Face Teaching. Proceedings of ASCILITE, Singapore.

6. Choi, H. J. and Johnson, S. (2005). The Effect of Context-Based Video Instruction on Learning and Motivation in Online Courses. The American Journal of Distance Education, 19(4), 215-227.

7. Cognition and Technology Group (1992) An Anchored Instruction Approach To Cognitive Skills Acquisition And Intelligent Tutoring. Cognitive Approaches to Automated, ed. J. W. Regian and V. J. Shute, 135-170. Hillsdale, NJ: Lawrence Erlbaum Associates, Inc.
8. Crystal Ball. (2008).
Available:

9. Free Online Surveys.Com. (2008). Available: http://www.freeonlinesurvey.com/).

10. Grossman, T. (2003). Getting down to business. ORMS Today, 30(4).

11. Heinrichs, L. R. \& McDonald, J. (2006). The State of IS Enrollments: Have We Turned the Corner?, Proceedings of the 2006 SWDSI Conference, Oklahoma City.

12. James. M., Laws, E., Staniland, K., Dowdle, D., and Mollo, B., (2004). Nuggets: Encouraging Academic Colleagues to Become Independent in Their Development of Media-enriched and Interactive Online Content., Proceedings: Education in a Changing Environment, University of Salford, UK.

13. Koohang, A. (2004). Creating Learning Objects in Collaborative E-Learning Settings, Issues in Information Systems, 5(2), 584-590.

14. Kozma, R. B. (1991). Learning with Media, Review of Educational Research, 61(2), 179-211.

15. Papanikolaou, K. A., Grigoriadou, M., Kornilakis, H. and Magoulas G. D. (2003). Personalizing the Interaction in a Web-based Educational Hypermedia System: the case of INSPIRE. User Modeling and User-Adapted Interaction, 13, 213-267.

16. Ragsdale, C. T. (2004). Spreadsheet Modeling and Decision Analysis. Thomson South-Western, Ohio.

17. Solver. (2008). Available: http://www.solver.com/.

18. Stain, S. Mitchell, M., Belue, R., Mosley, V., Wherry, S., Adamas, C. Z., et al (2005). Objective assessment of videoconferences lectures in a surgical clerkship. The American Journal of surgery, 189, 81-84.

19. Video Professor. (2008). Available: http://www.videoprofessor.com/.

20. What's Best!. (2008). Available: http://www.lindo.com/.

21. Whatley, J. and Ahmad, A. (2007). Using Video to Record Summary Lectures to Aid Students' Revision. Interdisciplinary Journal of Knowledge and Learning Objects, 3, 187-196.

22. Winston, W. L. \& Albright, S.C. (2001). Practical Management Science. Duxbury, California. 


\section{APPENDIX - Professor-Developed Video Survey}

\section{1) What is your classification?}

freshman

sophomore

junior

senior

graduate

2) What is your GPA?

$<2.00$

2.00 to 2.49

2.50 to 2.99

3.00 to 3.49

3.50 to 4.00

3) How many online courses have you taken, including those you are currently enrolled in?

0

$1-2$

3-4

5 or more

4) Please rate the usefulness of each of the following online course teaching tools as (1)

Very Useful, (2) Somewhat Useful, (3) Neutral, (4)

Somewhat unuseful (5) Not useful at all, and (6)

Have never used

Textbook

PowerPoint slides

Message boards

Chat rooms

Textbook/Publisher website

Textbook/Publisher videos

Student CD

Professor-developed videos

5) Of the online courses you have taken, including those you are currently enrolled in, how many use videos for instruction?

0

$1-2$

3-4

5 or more

6) Of the online courses you have taken that use video, how much time do/did you spend watching the videos each week?

0 minutes
1-30 minutes

31-60 minutes

61-90 minutes

91-120 minutes

more than 120 minutes

7) Of the online courses you have taken, including those you are currently enrolled in, how many use professor-developed videos for instruction?

0

$1-2$

3-4

5 or more

8) Please rate the following regarding professordeveloped videos used in online courses you have taken as (1) Strongly Agree (2) Agree (3) Neutral (4) Disagree (5) Strongly Disagree (6) NA

Enhances learning of spreadsheet skills

Enhances learning of math skills

Enhances textbook information

Replaces the textbook

Can be stopped/replayed as often as needed

Presented material is relevant

Video quality is adequate

Audio quality is adequate

Video size is adequate

Video length is adequate

Audio/video synchronization is adequate

Video can be copied to PC

Enough courses use professor-developed videos

9) What other benefits have you experienced from the use of professor-developed online course videos (open-ended)?

10) What drawbacks have you experienced from the use of professor-developed online course videos (open-ended)? 